\title{
Low genetic diversity in Persoonia mollis (Proteaceae), a fire-sensitive shrub occurring in a fire-prone habitat
}

\author{
SIEGFRIED L. KRAUSS* \\ Department of Biological Sciences, University of Wollongong, Northfields Avenue, Wollongong, NSW, 2522, \\ Australia
}

\begin{abstract}
Allozyme frequency data were used to estimate hierarchical levels of genetic diversity within and among the nine subspecies of the morphologically variable shrub Persoonia mollis $\mathrm{R}$. Br. (Proteaceae). This species is a fire-sensitive component of the fire-prone sclerophyllous vegetation of south-eastern Australia. The total gene diversity $\left(H_{\mathrm{T}}=0.139\right)$ within $P$. mollis was less than half that typically found within angiosperm species. However, $P$. mollis was typical of angiosperms in the way its gene diversity was distributed, with 78.3 per cent of the total gene diversity found within populations. Of the 21.7 per cent found among populations, 17.9 per cent was attributed to differences among subspecies and only 3.8 per cent attributed to differences among populations within subspecies. Heterozygosity $\left(H_{\mathrm{E}}\right)$ within populations varied 10-fold from $0.023-0.206$, with a comparatively low mean over all populations of 0.109 . A significant deficit of heterozygotes for the outbreeding $P$. mollis is consistent with the 'heterozygosity paradox', is caused by a Wahlund effect, and suggests an average genetic neighbourhood size of between 3 and 60 plants. Explanations for these patterns and the weak correlation of these data with morphological variation are discussed. It is suggested that the high frequency and haphazard occurrence of fire plays a major role in affecting the levels and distribution of genetic diversity within $P$. mollis, and probably within other fire-sensitive plant species also occurring in fire-prone habitats, through relatively frequent localized extinction and subsequent recolonization.
\end{abstract}

Keywords: allozymes, fire, genetic diversity, genetic neighbourhood, population extinction, recolonization.

\section{Introduction}

The characterization of levels of genetic variation within and among natural populations is essential for an understanding of the evolutionary processes that bring about divergence within species and perhaps ultimately speciation. Recent extensive reviews enable the comparison of allozyme variation within a study species to a large number of taxa with similar life history and ecological characteristics (Hamrick \& Godt, 1989; Hamrick et al., 1992). Strong associations between patterns of allozyme diversity and some species traits such as distribution size and breeding system have been found (Hamrick \& Godt, 1989). However, as much as 60 per cent of

\footnotetext{
*Current address: Division of Botany and Zoology, The Australian National University, ACT, 0200, Australia. E-mail: siegy.krauss@anu.edu.au
}

the variation among species is not accounted for by these characteristics (Hamrick et al., 1992). Historical factors such as population bottlenecks, founder events or local extinctions caused by for example climatic changes during glaciations have often been proposed to account for unusual levels of genetic diversity that are not explained by life history or ecological characteristics (e.g. Moran et al., 1989; Haase, 1992; Qiu \& Parks, 1994; Lewis \& Crawford, 1995). However, the effect of historical patterns of high fire frequency on genetic diversity within plant species that have evolved under high fire regimes has rarely been discussed. The widespread sclerophyllous vegetation of Australia has evolved under high fire frequencies since human occupation at least 30000 years before present (Singh et al., 1981). I suggest here that unusually low levels of allozyme variability in Persoonia mollis, a fire-sensitive plant species occurring in a fire-prone habitat, may 
primarily result from the effect of historical patterns of high fire frequency and intensity haphazardly causing local extinctions and subsequent recolonizations.

Persoonia mollis R. Br. (Proteaceae) is, morphologically, an extremely variable species within which nine subspecies are currently recognized (Krauss \& Johnson, 1991). These subspecies occur more or less continuously (with the exception of the disjunct subspecies maxima) over a range of substrates and climatic conditions within eucalypt-dominated dry sclerophyll forests and heaths of south-eastern Australia (Fig. 1). Narrow transition zones between parapatric subspecies occur at ecotones (Krauss, in press). All subspecies are cross-compatible, and pollinators do not discriminate between subspecies at transition zones (Krauss, 1995). Although selfcompatible, $P$. mollis is completely outcrossing in natural populations (Krauss, 1994). Pollen dispersal, facilitated by a suite of bees, is extremely restricted with genetic neighbourhood sizes (Wright, 1946) resulting from pollen dispersal alone amongst the smallest recorded (Krauss, 1994). However, in contrast to the expectation that small population size leads to biparental inbreeding and reduced heterozygosity compared to Hardy-Weinberg expectations (Turner et al., 1982), a slight excess of heterozygotes was found in the seed cohort (Krauss, 1994). The most likely explanation of this apparent paradox is that seed dispersal is a substantially larger component of gene flow than pollen dispersal in $P$. mollis (Krauss, 1994). Gene flow via seed dispersal is potentially high as seeds are primarily gravity dispersed and secondarily ingested and dispersed by large birds such as Currawongs (Strepera sp.) with often large ranges. The validity of these conclusions can be tested by an analysis of hierarchical patterns of genetic differentiation, because under certain assumptions (Slatkin, 1987; Porter, 1990) genetic structure is directly related to historical levels of gene flow.

In this paper, hierarchical patterns of gene diversity within $P$. mollis are characterized and compared to those of other species with similar life history and ecological characteristics. Possible explanations to account for the patterns of genetic variation within P. mollis are discussed.

\section{Materials and methods}

Two populations from each of the nine subspecies within $P$. mollis were sampled (Fig. 1). Two exceptions to this were subspecies maxima, where only one population was sampled because it was the only
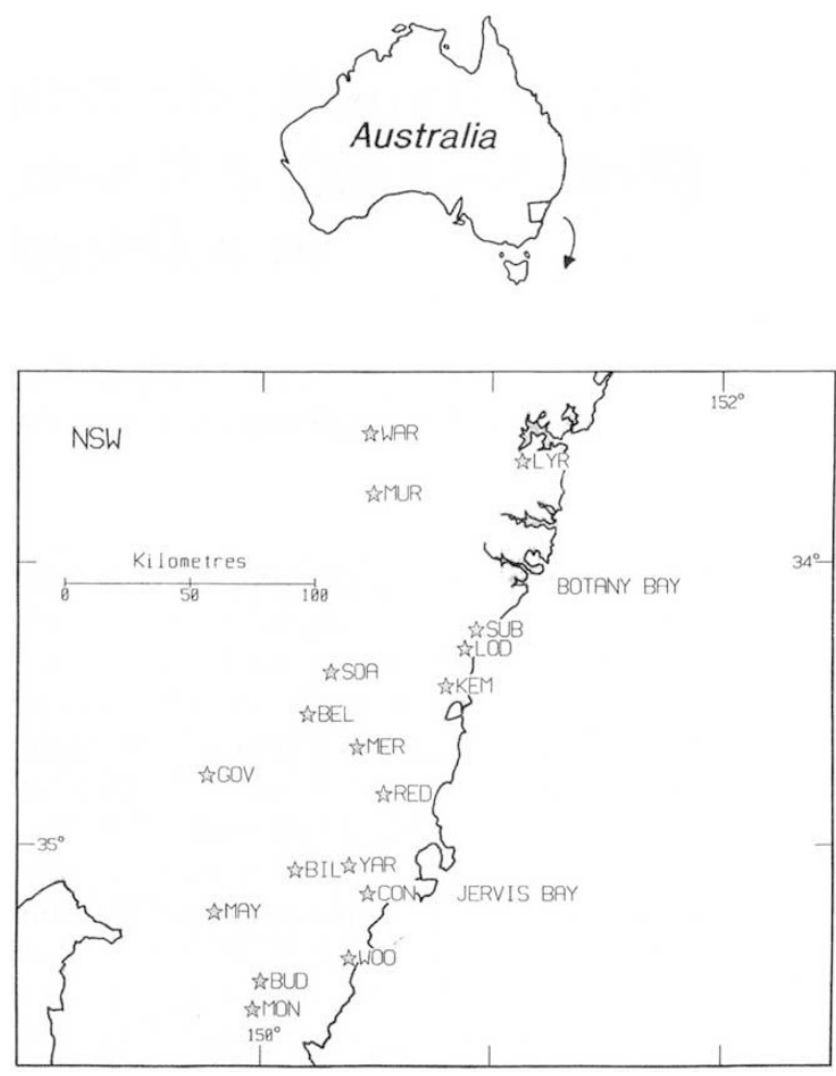

Fig. 1 The location of 18 populations of Persoonia mollis that were each sampled for allozyme diversity at 11 variable loci. Populations and subspecies (italics) are: LYR, Lyrebird Gully, maxima; WAR, Waratah Park, mollis; MUR, Murphys Glen, mollis; SUB, Sublime Point, nectens; LOD, Loddon Falls, nectens; KEM, Mt. Kembla, nectens; SOA, Soapy Flat, revoluta; BEL, Belanglo State Forest, revoluta; MER, Meryla State Forest, ledifolia; RED, Red Rocks Nature Reserve, ledifolia; YAR, Yarramunmun Fire Trail, leptophylla; BIL, Billys Hill, leptophylla; GOV, Governors Hill, livens; MAY, Mayfield, livens; CON, Conjola State Forest, caleyi; WOO, Woodburn State Forest, caleyi; BUD, Mt. Budawang, budawangensis; MON, Monga State Forest, budawangensis.

known population of this subspecies, and subspecies nectens, where three populations were sampled because the populations were small in size. Sampling involved the random collection of at least two buds from each plant just prior to anthesis. These were immediately stored in liquid nitrogen and later at $-80^{\circ} \mathrm{C}$ until electrophoresis. Sample sizes less than 70 plants indicate that the entire population was sampled. Sample sizes between 70 and 86 were random samples of larger populations.

For each individual, eight anthers were ground in chilled ceramic spot plates in one drop of Tris- $\mathrm{HCl}$

(C) The Genetical Society of Great Britain, Heredity, 78, 41-49. 
pH 7.5 grinding buffer (Soltis et al., 1983), and the extract soaked onto paper wicks which were then loaded into gels for electrophoresis. An extensive range of enzymes, buffers and running conditions was tested, and only optimal conditions that produced clearly variable and reproducible results are reported here. Electrophoresis was conducted with 12 per cent w/v starch gels in either a TrisMaleate (TM) buffer solution at pH 7.4 (Selander $e t$ al., 1971), or a Tris-Borate-EDTA (TBE) buffer solution at $\mathrm{pH} 8.6$ (Wendel \& Weeden, 1989). Gels were run for $16 \mathrm{~h}$ at $4^{\circ} \mathrm{C}$, and at $90 \mathrm{~mA}$ for TM systems, and $120 \mathrm{~V}$ for TBE systems. TM system gels were stained for phosphoglucomutase (PGM, EC 5.4.2.2), glucose-6-phosphate isomerase (GPI, EC 5.3.1.9) and phosphogluconate dehydrogenase (PGD, EC 1.1.1.44). TBE system gels were stained for aspartate aminotransferase (AAT, EC 2.6.1.1) and peptidase (PEP, with a substrate of L-leucylL-tyrosine, EC 3.4.-.-). Stain recipes were taken from Wendel \& Weeden (1989), except for PEP, which was as follows: L-leucyl-L-tyrosine $(20 \mathrm{mg})$ and o-dianisidine $(5 \mathrm{mg})$ dissolved in 2 drops $0.1 \mathrm{M} \mathrm{HCl}$, with L-amino acid oxidase $(5 \mathrm{mg})$, horseradish peroxidase (5 mg) and $25 \mathrm{~mL}$ phosphate buffer, pH 7. The genetic basis of allozyme banding patterns was confirmed by segregation patterns in seeds following both controlled and open pollination (Krauss, 1995). Isozymes and alleles were numbered sequentially, with the most anodal (i.e. fastest running) being designated first.

Standard estimates of genetic variability (mean number of alleles per locus, percentage of loci polymorphic, observed and expected (unbiased by sample size) heterozygosity averaged over all loci, and Wright's fixation index $(F)$ ) were calculated for each population using BIosys-1 (Swofford \& Selander, 1989). The deviation of $F$ from 0 was tested by $\chi_{1}^{2}=n F^{2}$, where $n=$ the mean number of individuals in the population (Nei, 1987). Each variable locus in each population was tested for departure from Hardy-Weinberg equilibrium by exact tests (Lessios, 1992) where, in the case of more than two alleles at a locus, genotypes were pooled into three classes. Significance levels were adjusted by the standard Bonferroni technique of dividing the predetermined significance level $(P=0.05)$ by the number of tests (116) to obtain the corrected significance level $(P=0.0004)$ (Lessios, 1992).

The partitioning of genetic variation at each hierarchical level (i.e. within populations, among populations within subspecies, among subspecies within the species, and among populations within the species) was estimated by gene diversity statistics unbiased for sample size (Nei \& Chesser, 1983) using GENESTAT-PC 3.3 (Whitkus, 1988). The total gene diversity $\left(H_{\mathrm{T}}\right)$ (where $H_{\mathrm{T}}$ at a single locus is the unbiased heterozygosity expected under HardyWeinberg equilibrium) was partitioned hierarchically as follows: $H_{\mathrm{T}}=H_{\mathrm{P}}+D_{\mathrm{PS}}+D_{\mathrm{ST}}$, where $D_{\mathrm{PS}}=H_{\mathrm{S}}-H_{\mathrm{P}}$ is the gene diversity among populations within subspecies, $D_{\mathrm{ST}}=H_{\mathrm{T}}-H_{\mathrm{S}}$ is the gene diversity among subspecies within the total gene diversity, and $H_{\mathrm{P}}$ and $H_{\mathrm{S}}$ are the unbiased gene diversities within populations and subspecies, respectively. The ratios of $D_{\mathrm{PS}}, D_{\mathrm{ST}}$ and $D_{\mathrm{PT}}$ to the total gene diversity $H_{\mathrm{T}}$ were calculated to assess the proportion of gene diversity at each hierarchical level. Thus $G_{\mathrm{PS}}=\left(H_{\mathrm{S}}-H_{\mathrm{P}}\right) / H_{\mathrm{T}}, G_{\mathrm{ST}}=\left(H_{\mathrm{T}}-H_{\mathrm{S}}\right) / H_{\mathrm{T}}$ and $G_{\mathrm{PT}}=\left(H_{\mathrm{T}}-H_{\mathrm{P}}\right) / H_{\mathrm{T}}$, where $H_{\mathrm{P}}, H_{\mathrm{S}}$ and $H_{\mathrm{T}}$ were first averaged over loci. The error of $G_{X Y}$ was approximated over estimates of $G_{X Y}$ for each locus.

Overall similarity of populations was assessed by Nei's genetic distance, unbiased for sample size (Nei, 1978). Results are presented graphically by the ordination procedure nonmetric multidimensional scaling (Lessa, 1990).

\section{Results}

Allele frequencies and sample sizes for 11 variable loci in 18 populations of $P$. mollis are available on request from the author. Significant differences among populations were found in allele frequencies for all loci except Pgd-2. However, for most loci, significant deviation in the frequency of the most common allele was restricted to one or a few populations. The locus Aat-3 was an exception to this in being highly variable across most populations.

The low levels of genetic variability within populations of $P$. mollis are summarized in Table 1 . The expected heterozygosity $\left(H_{\mathrm{E}}\right)$ varied among populations from 0.023 at Mt Kembla to 0.206 at Governors Hill, with a mean across populations of 0.109 . The subspecies livens populations were the most heterozygous, and more generally the southern populations showed higher levels of heterozygosity (Table 1). Estimates of Wright's fixation index $(F)$ were not significantly different from zero in any population. However, the ratio of positive:negative $F$ for all populations was $11: 3(F>0 ; P<0.05$; signtest) and the mean $F$ of 0.049 (SE 0.022) was in excess of 0 ( $t$-test; $P<0.05)$, although this was largely influenced by the $F$ of 0.336 for the extremely small and disjunct population Lyrebird Gully. No significant departures from $\mathrm{H}-\mathrm{W}$ equilibrium were detected. 
Table 1 Estimates of genetic variability for Persoonia mollis based on 11 variable loci in 18 populations

\begin{tabular}{|c|c|c|c|c|c|c|}
\hline Population & $N$ & $A$ & $P$ & $H_{\mathrm{O}}$ & $H_{\mathrm{E}}$ & $F$ \\
\hline Belanglo & $\begin{array}{c}71.0 \\
(1.3)\end{array}$ & $\begin{array}{c}1.7 \\
(0.2)\end{array}$ & 54.5 & $\begin{array}{c}0.081 \\
(0.044)\end{array}$ & $\begin{array}{c}0.083 \\
(0.045)\end{array}$ & 0.024 \\
\hline Soapy Flat & $\begin{array}{l}40.9 \\
(0.1)\end{array}$ & $\begin{array}{c}1.6 \\
(0.2)\end{array}$ & 54.5 & $\begin{array}{c}0.090 \\
(0.053)\end{array}$ & $\begin{array}{c}0.093 \\
(0.058)\end{array}$ & 0.032 \\
\hline Murphys Glen & $\begin{array}{l}72.1 \\
(0.9)\end{array}$ & $\begin{array}{c}2.0 \\
(0.2)\end{array}$ & 72.7 & $\begin{array}{c}0.159 \\
(0.046)\end{array}$ & $\begin{array}{c}0.159 \\
(0.046)\end{array}$ & 0.000 \\
\hline Waratah & $\begin{array}{l}72.0 \\
(0.0)\end{array}$ & $\begin{array}{c}1.5 \\
(0.2)\end{array}$ & 54.5 & $\begin{array}{c}0.067 \\
(0.031)\end{array}$ & $\begin{array}{c}0.060 \\
(0.027)\end{array}$ & -0.117 \\
\hline Lyrebird Gully & $\begin{array}{l}15.0 \\
(0.0)\end{array}$ & $\begin{array}{c}1.3 \\
(0.1)\end{array}$ & 27.3 & $\begin{array}{c}0.073 \\
(0.046)\end{array}$ & $\begin{array}{c}0.110 \\
(0.062)\end{array}$ & 0.336 \\
\hline Loddon Falls & $\begin{array}{l}15.0 \\
(0.0)\end{array}$ & $\begin{array}{c}1.2 \\
(0.1)\end{array}$ & 18.2 & $\begin{array}{c}0.061 \\
(0.049)\end{array}$ & $\begin{array}{c}0.059 \\
(0.047)\end{array}$ & -0.034 \\
\hline Sublime Pt & $\begin{array}{c}8.0 \\
(0.0)\end{array}$ & $\begin{array}{c}1.3 \\
(0.2)\end{array}$ & 18.2 & $\begin{array}{c}0.057 \\
(0.039)\end{array}$ & $\begin{array}{c}0.067 \\
(0.049)\end{array}$ & 0.149 \\
\hline Mt. Kembla & $\begin{array}{c}52.0 \\
(0.0)\end{array}$ & $\begin{array}{c}1.3 \\
(0.1)\end{array}$ & 27.3 & $\begin{array}{c}0.021 \\
(0.016)\end{array}$ & $\begin{array}{c}0.023 \\
(0.015)\end{array}$ & 0.087 \\
\hline Red Rocks & $\begin{array}{l}74.0 \\
(0.0)\end{array}$ & $\begin{array}{c}1.8 \\
(0.2)\end{array}$ & 72.7 & $\begin{array}{c}0.059 \\
(0.035)\end{array}$ & $\begin{array}{c}0.059 \\
(0.036)\end{array}$ & 0.000 \\
\hline Meryla & $\begin{array}{l}80.2 \\
(1.2)\end{array}$ & $\begin{array}{c}2.3 \\
(0.2)\end{array}$ & 81.8 & $\begin{array}{c}0.091 \\
(0.021)\end{array}$ & $\begin{array}{c}0.090 \\
(0.020)\end{array}$ & -0.011 \\
\hline Conjola & $\begin{array}{l}73.5 \\
(0.8)\end{array}$ & $\begin{array}{c}2.2 \\
(0.3)\end{array}$ & 72.7 & $\begin{array}{c}0.133 \\
(0.050)\end{array}$ & $\begin{array}{c}0.133 \\
(0.047)\end{array}$ & 0.000 \\
\hline Woodburn & $\begin{array}{l}77.0 \\
(0.0)\end{array}$ & $\begin{array}{c}2.1 \\
(0.3)\end{array}$ & 72.7 & $\begin{array}{c}0.119 \\
(0.049)\end{array}$ & $\begin{array}{c}0.127 \\
(0.052)\end{array}$ & 0.063 \\
\hline Budawang & $\begin{array}{l}70.9 \\
(0.1)\end{array}$ & $\begin{array}{c}2.5 \\
(0.3)\end{array}$ & 81.8 & $\begin{array}{c}0.109 \\
(0.047)\end{array}$ & $\begin{array}{c}0.110 \\
(0.045)\end{array}$ & 0.009 \\
\hline Monga & $\begin{array}{c}85.5 \\
(0.5)\end{array}$ & $\begin{array}{c}2.0 \\
(0.3)\end{array}$ & 72.7 & $\begin{array}{c}0.128 \\
(0.052)\end{array}$ & $\begin{array}{c}0.139 \\
(0.060)\end{array}$ & 0.079 \\
\hline Gov. Hill & $\begin{array}{l}77.8 \\
(2.6)\end{array}$ & $\begin{array}{c}1.6 \\
(0.2)\end{array}$ & 45.5 & $\begin{array}{c}0.181 \\
(0.068)\end{array}$ & $\begin{array}{c}0.206 \\
(0.074)\end{array}$ & 0.121 \\
\hline Mayfield & $\begin{array}{l}71.5 \\
(2.5)\end{array}$ & $\begin{array}{c}1.8 \\
(0.2)\end{array}$ & 72.7 & $\begin{array}{c}0.178 \\
(0.071)\end{array}$ & $\begin{array}{c}0.185 \\
(0.073)\end{array}$ & 0.038 \\
\hline Billys Hill & $\begin{array}{l}74.2 \\
(0.4)\end{array}$ & $\begin{array}{c}2.5 \\
(0.3)\end{array}$ & 72.7 & $\begin{array}{c}0.124 \\
(0.046)\end{array}$ & $\begin{array}{c}0.139 \\
(0.051)\end{array}$ & 0.108 \\
\hline Yarramunmun & $\begin{array}{l}70.5 \\
(0.4)\end{array}$ & $\begin{array}{c}2.6 \\
(0.3)\end{array}$ & 81.8 & $\begin{array}{c}0.116 \\
(0.042)\end{array}$ & $\begin{array}{c}0.116 \\
(0.041)\end{array}$ & 0.000 \\
\hline $\begin{array}{l}\text { Mean } \\
\text { SE }\end{array}$ & & 1.85 & 58.6 & 0.103 & 0.109 & $\begin{array}{l}0.049 \\
0.022\end{array}$ \\
\hline
\end{tabular}

A locus is considered polymorphic if more than one allele was detected; expected heterozygosities are unbiased estimates (see Nei, 1978). $A$, mean number of alleles per locus; $P$, percentage of loci polymorphic; $H_{\mathrm{O}}$, observed heterozygosity averaged over all loci; $H_{\mathrm{E}}$, Hardy-Weinberg expected heterozygosity (unbiased); $F$, Wright's fixation index; $\mathrm{SE}$ in parentheses.

The total unbiased gene diversity $\left(H_{\mathrm{T}}\right)$ was 0.139 , with 78.3 per cent of this variation occurring within populations and 21.7 per cent among populations (Table 2). When the 21.7 per cent of the gene diversity apportioned among populations was partitioned into within- and among-subspecies components, 17.9 per cent was attributed to differences among subspe- cies, with only 3.8 per cent attributed to differences among populations within subspecies (Table 2). For comparison to Hamrick \& Godt (1989), the biased estimates of the distribution of gene diversity were $G_{\mathrm{PS}}=0.022, G_{\mathrm{ST}}=0.157$ and $G_{\mathrm{PT}}=0.179$.

The ordination of populations based on Nei's (1978) unbiased genetic distances reveals the relative 
Table 2 Distribution of gene diversity (unbiased for sample size) among nine subspecies and 18 populations of Persoonia mollis

\begin{tabular}{lcccrcr}
\hline Locus & $H_{\mathrm{P}}$ & $H_{\mathrm{S}}$ & $H_{\mathrm{T}}$ & \multicolumn{1}{c}{$G_{\mathrm{PS}}$} & $G_{\mathrm{ST}}$ & $G_{\mathrm{PT}}$ \\
\hline Pgm-1 & 0.181 & 0.181 & 0.225 & 0.000 & 0.196 & 0.195 \\
Gpi-1 & 0.011 & 0.012 & 0.013 & 0.069 & 0.047 & 0.115 \\
Gpi-2 & 0.113 & 0.144 & 0.195 & 0.156 & 0.262 & 0.418 \\
Aat-1 & 0.105 & 0.108 & 0.145 & 0.016 & 0.255 & 0.272 \\
Aat -2 & 0.041 & 0.068 & 0.104 & 0.265 & 0.343 & 0.608 \\
Aat-3 & 0.332 & 0.313 & 0.369 & -0.052 & 0.154 & 0.102 \\
Pgd-1 & 0.146 & 0.153 & 0.169 & 0.041 & 0.097 & 0.138 \\
Pgd-2 & 0.020 & 0.019 & 0.019 & -0.041 & 0.002 & -0.041 \\
Pgd-3 & 0.049 & 0.054 & 0.057 & 0.089 & 0.058 & 0.147 \\
Pep-1 & 0.117 & 0.114 & 0.121 & -0.019 & 0.053 & 0.035 \\
Pep-2 & 0.082 & 0.089 & 0.111 & 0.065 & 0.199 & 0.263 \\
Mean & 0.109 & 0.114 & 0.139 & 0.038 & 0.179 & 0.217 \\
SE & 0.027 & 0.025 & 0.031 & 0.028 & 0.033 & 0.055 \\
\hline
\end{tabular}

$H_{\mathrm{T}}$, total gene diversity; $H_{\mathrm{s}}$, mean gene diversity within subspecies; $H_{\mathrm{P}}$, mean gene diversity within populations; $G_{\mathrm{PS}}=\left(H_{\mathrm{S}}-H_{\mathrm{P}}\right) / H_{\mathrm{T}} ; G_{\mathrm{ST}}=\left(H_{\mathrm{T}}-H_{\mathrm{S}}\right) / H_{\mathrm{T}}$; $G_{\mathrm{PT}}=\left(H_{\mathrm{T}}-H_{\mathrm{P}}\right) / H_{\mathrm{T}}$.

genetic distinctness of the subspecies livens and subspecies maxima populations from all others (Fig. 2). The maximum genetic distance was 0.14 between Lyrebird Gully (subspecies maxima) and Governors Hill (subspecies livens) populations. All other genetic distances were below 0.10. Also striking is the congruence of genetic identity to geographical distance among populations, with the notable exception of the populations of the parapatric subspecies budawangensis and livens. These patterns are shown more clearly by plotting genetic distance against geographical distance (Fig. 3a). This plot suggests that population structure is affected by isolation by distance, although there is a wide dispersion of points suggesting other confounding factors. Closer examination of Fig. $3 a$ reveals that almost all points above the line of best fit involve the populations from subspecies livens, maxima and budawangensis. Plotting genetic distance against geographical distance for all populations except those from these three subspecies (Fig. $3 b$ ) reveals a spread of points with little correlation between genetic and geographical distance.

\section{Discussion}

The total gene diversity within $P$. mollis $\left(H_{\mathrm{T}}=0.139\right.$; $\mathrm{SE}=0.031$ ) is less than half the average gene diversity for woody angiosperm species $\left(H_{\mathrm{T}}=0.287\right.$; $\mathrm{SE}=0.016 ; n=73$ ) and for plant species in general

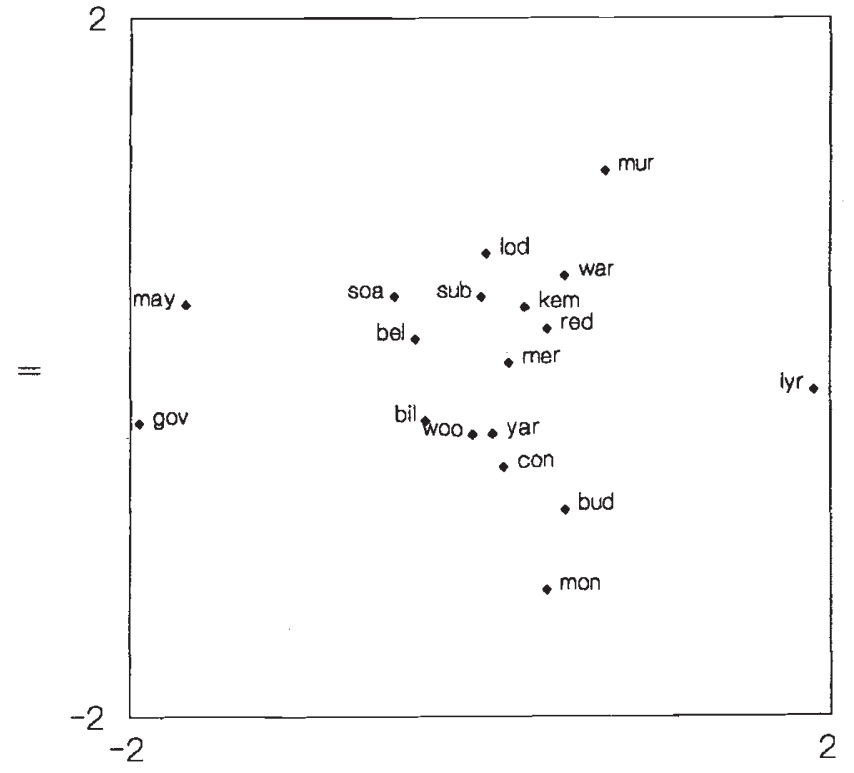

Fig. 2 Ordination of 18 populations of Persoonia mollis by multidimensional scaling of Nei's unbiased genetic distance from allozyme frequency data. Stress $=0.103$.

$\left(H_{\mathrm{T}}=0.310 ; \mathrm{SE}=0.007 ; n=406\right)$ (Hamrick \& Godt, 1989; Hamrick et al., 1992). Similarly, the average gene diversity within populations of $P$. mollis $\left(H_{\mathrm{P}}=0.109 ; \mathrm{SE}=0.027\right)$ is less than half that found 

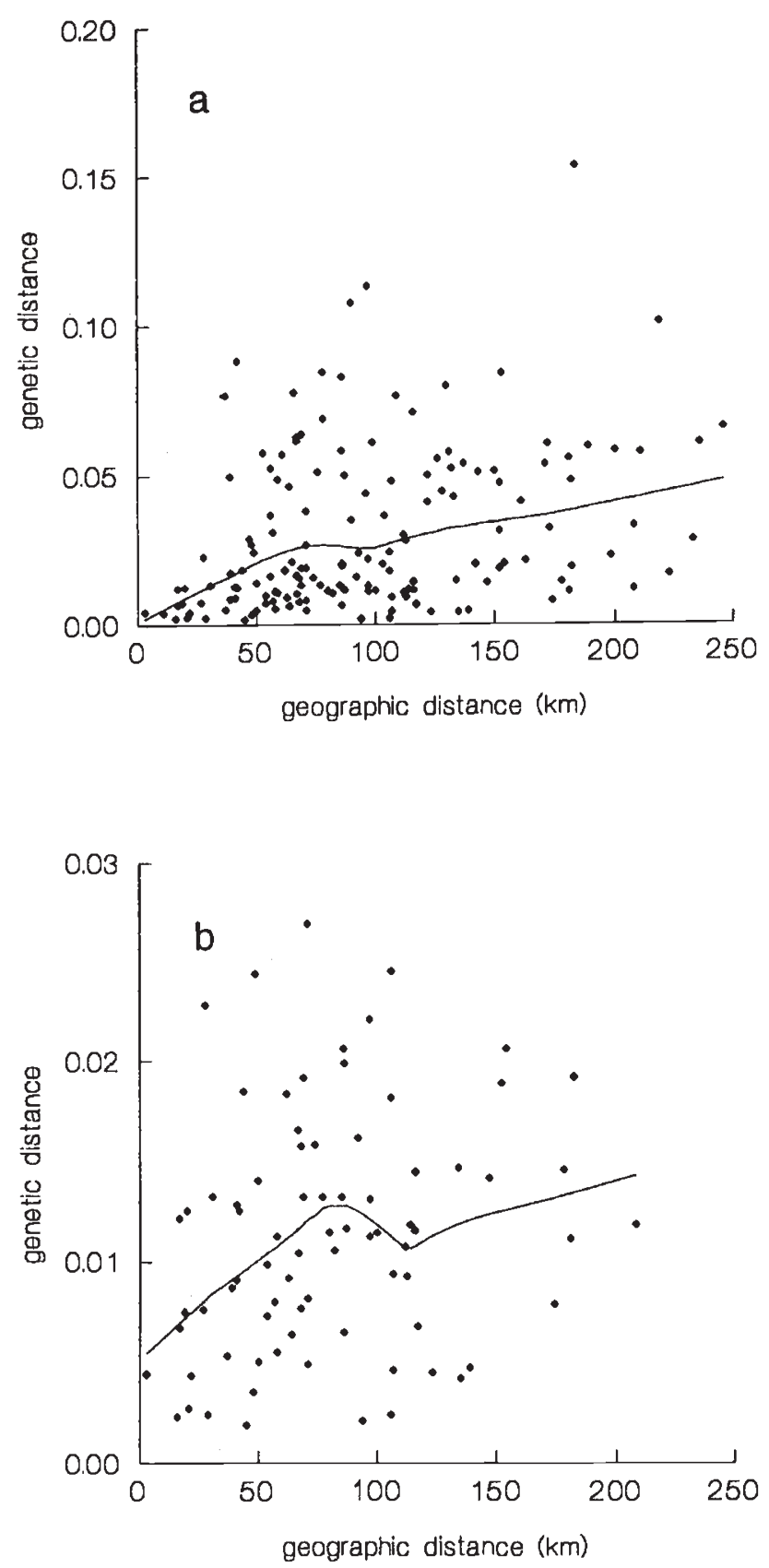

Fig. 3 Plot of genetic distance (Nei's unbiased) against geographical distance for (a) 18 populations of Persoonia mollis, and (b) 13 populations of $P$. mollis (i.e. as for (a) but without the subspecies livens, maxima and budawangensis populations), each with a locally weighted line of best fit (see text). Note the difference in scale for genetic distance between (a) and (b).

on average within populations of woody angiosperm species $\left(H_{\mathrm{p}}=0.249 ; \mathrm{SE}=0.014 ; n=73\right)$ and for plant species in general $\left(H_{\mathrm{P}}=0.230 ; \mathrm{SE}=0.007\right.$; $n=406$ ) (Hamrick \& Godt, 1989; Hamrick et al., 1992).
However, this low gene diversity is typically distributed among populations within $P$. mollis, where 17.9 per cent (21.7 per cent unbiased; $\mathrm{SE}=5.5$ per cent) of the gene diversity is found among populations, which compares to an average of 22.4 per cent ( $\mathrm{SE}=1.2$ per cent; $n=406)$ for plant species in general (Hamrick \& Godt, 1989). Hamrick \& Godt (1989) found that the variation in diversity among populations was influenced mainly by plant breeding systems. The proportion of gene diversity among populations within $P$. mollis (17.9 per cent) is comparable to an average of 19.7 per cent ( $\mathrm{SE}=1.7$ per cent; $n=124$ ) for other outcrossing, animal-pollinated species (Hamrick \& Godt, 1989). Therefore, $P$. mollis is typical in the way its gene diversity is distributed among populations, but atypical in that it has less than half the gene diversity found typically in plant species.

A scenario of frequent extinctions and recolonizations has often been proposed to explain low levels of genetic diversity within species (Moran et al., 1989; Haase, 1992; Qiu \& Parks, 1994). These are usually linked to changing climatic conditions and/or changes in sea levels associated with glacial/interglacial periods during the Pleistocene. Populations are restricted to refugia during the harshest climatic conditions, expanding in range during improved conditions. However, south-eastern Australia has been relatively stable through recent geological time and glaciations have had little impact on modern vegetation distributions in this area (Hope, 1984). The lack of obvious refugia coupled with the relatively restricted distribution of $P$. mollis makes this scenario even more unlikely. Further, the distribution of gene diversity among populations is expected to be lower than on average under such a scenario as populations would diverge whilst in isolation (e.g. Haase, 1992). This was not the case in $P$. mollis.

Alternatively, increased fire regimes coupled with the onset of cold-arid conditions during the past 30000 years or so in Australia (Singh et al., 1981; Hope, 1984) has probably caused increasingly frequent extinction and recolonization events for fire-sensitive plant species. Fire-sensitive species are obligate seeders as adult plants, and are killed outright by fire, whereas fire-tolerant species resprout from lignotubers or epicormic buds. Fire frequency is known to play a critical role in the structure, composition and long-term persistence of plant populations (Bradstock, 1990; Cary \& Morrison, 1995). Repeated fires with an interval of less than 5 to 8 years would not allow sufficient time for many woody fire-sensitive species (such as $P$. mollis) to produce a new seed bank, eliminating them from 
an area. For example, Siddiqi et al. (1976) recorded the localized elimination of the woody fire-sensitive species Banksia ericifolia, Hakea teretifolia (both Proteaceae) and Allocasuarina distyla by repeated burning. This may explain the current absence of $P$. mollis from Royal National Park, an area of apparently suitable habitat just north of the $P$. mollis ssp. nectens populations that has been regularly and extensively burnt in the recent past.

The haphazard nature of the occurrence and intensity of fire would mean that an overall reduction in the distribution of gene diversity among populations would not necessarily be expected, as isolated rather than broad-scale extinctions would occur and recolonizations would be frequent and rapid relative to glacial/interglacial events. This haphazard nature of extinction and recolonization can also explain the wide dispersion of points on the plot of genetic distance against geographical distance (Fig. 3), as time since the last fire would affect the current level of genetic diversity in a population.

Other studies of allozyme variation in the Proteaceae reveal similarly low levels of genetic diversity by measures of heterozygosity and/or percentage variable loci within species (Coates \& Sokolowski, 1992; Carthew, 1993; Ayre et al., 1994; Sampson et al., 1994). For example, Coates and Sokolowski (1992) found an expected heterozygosity averaged over six populations of Banksia cuneata of only 0.08, and a total genetic diversity $\left(H_{\mathrm{T}}\right)$ of 0.22 . Preliminary studies indicate that genetic diversity within the closely related Persoonia linearis is comparable to that in P. mollis (Krauss, 1995). Although further studies are required, the sclerophyllous Proteaceae appear in general to be depauperate for variation at the allozyme loci typically studied. The Proteaceae are a common fire-sensitive component of fire-prone sclerophyllous habitats (Benson, 1985) and it may be that high fire frequency plays an important role in affecting gene diversity not only within these species but also more generally within the family. Further studies, particularly contrasting the extent and nature of genetic differentiation within other firesensitive Proteaceous (and non-Proteaceous) species occurring in fire-prone habitats and those occurring in non-fire-prone habitats, are required to assess these conclusions further. All else being equal, the general expectation is that fire-sensitive species will be less genetically diverse than fire-tolerant species.

Although Wright's fixation index $(F)$ was not significantly different from zero in any of 18 populations of $P$. mollis, when averaged over populations an overall deficit of heterozygotes compared to panmic- tic expectations was found $(F=0.049)$. The significantly positive $F$ for the outbreeding $P$. mollis is consistent with the 'heterozygosity paradox' (Brown, 1979), where outbreeding species tend to show a deficit of heterozygotes and inbreeders show an excess of heterozygotes compared to panmictic expectations. Direct estimates of outcrossing were consistently not different from, or in excess of, unity (Krauss, 1994), which indicates that inbreeding resulting from self-fertilization is not the cause of $F>0$ (Brown, 1979). Consequently, the Wahlund effect is biasing $F$ upwards (Brown, 1979); that is, some sampled populations comprise genetically heterogeneous subpopulations that do not constitute one panmictic unit. Heterogeneity of subpopulation gene frequencies could arise from heterogeneity of selection pressure, very small neighbourhood sizes within which random divergence may have occurred (Brown, 1979), or from stochastic disturbance such as occasional long-distance seed dispersal and establishment into what is here treated as a single population. Direct estimates of neighbourhood size based on the pollen-dispersal component of gene flow only were extremely small and within the range of 1-5 plants (Krauss, 1994). The results of the current study suggest that average seed dispersal increases neighbourhood size to a value less than the mean population sample size in the current study of c. 60 plants. A slight deficit of heterozygotes in the adult population compares to a slight excess of heterozygotes in the seed cohort (Krauss, 1994), which either reflects the Wahlund effect on the larger adult sample size, or alternatively suggests that any fitness effect associated with increased heterozygosity (Ledig, 1986) at the seed stage is not carried through to adulthood in $P$. mollis. This second scenario appears unlikely as many plants show a positive relationship between genetic heterozygosity and growth (Mitton \& Grant, 1984).

The weak correlation between genetic and geographical distance for populations of $P$. mollis sspp. mollis, nectens, ledifolia, revoluta, leptophylla and caleyi supports a scenario of gene flow through frequent population extinctions with subsequent recolonization, in which new populations are founded by occasional long-distance seed dispersal. These results are consistent with predictions of the model of Slatkin (1987), who suggested that extinction and recolonization can be an important cause of homogenizing gene flow. However, using Slatkin's equations Wade \& McCauley (1988) suggest that it is only when $K$ (the number of seeds colonizing new populations) is considerably larger than $\mathrm{Nm}$ (the number of seeds moving between extant popula- 
tions) that extinction and colonization reduce genetic differentiation. This situation arises for firesensitive plants if fire is a necessary precursor for seed germination and establishment at a site, either through soil preparation or removal of existing vegetation. Although more work is needed on the germination requirements of $P$. mollis seeds, this situation may apply.

Stabilizing selection is a possible but unlikely explanation of the weak correlation as it is improbable that stabilizing selection would affect all variable loci equally (Slatkin, 1987). In either case, these results indicate a lack of congruence between morphological and allozyme frequency variation (Krauss, in press). Strong natural selection for morphological form under different environmental conditions despite homogenizing levels of gene flow is a scenario consistent with the patterns of morphological and allozyme frequency variation within $P$. mollis. Hybrid zones between parapatric subspecies within $P$. mollis can be viewed as being semipermeable to gene flow (i.e. permeable to neutral allozyme coding genes and impermeable to genes coding for morphological form that are differentially selected against either side of an ecotone). However, the observation that most of the genetic diversity apportioned among populations was attributable to differences among subspecies suggests some weak linkage between these sets of genes.

A particularly striking pattern of genetic variation within $P$. mollis is the 10 -fold difference in heterozygosity from a low of 0.02 at Mt. Kembla to a high of 0.21 at Governors Hill. Heterozygosity was not correlated with population size, and the more important ecological determinates of genetic variation such as reproductive biology (Hamrick \& Godt, 1989 ) are consistent among populations within $P$. mollis. These observations support the conclusions made above that historical rather than current ecological factors are more important determinates of the levels of genetic diversity within $P$. mollis populations. In their survey of life history and ecological determinates of genetic diversity within woody plant species, Hamrick et al. (1992) found that these traits account for less than 40 per cent of the variation among species. Other factors, and particularly the evolutionary history of populations and species, play a major role in determining the levels and distribution of genetic diversity within species (Hamrick et al., 1992; Lewis \& Crawford, 1995). High fire frequency appears to play a vital role in affecting the levels and distribution of genetic diversity within $P$. mollis and probably other firesensitive plant species occurring in fire-prone communities that have evolved under high-fire regimes.

\section{Acknowledgements}

Field work was undertaken under NSW National Parks and Wildlife Service permit no. B/403 and Forestry Commission of NSW permit nos 3895 and 4565. This work was funded by an Australian Postgraduate Research Award. Assistance from the Royal Botanic Gardens, Sydney, and support from the Linnean Society of NSW via a Linnean Macleay Fellowship and two Joyce W. Vickery Research Fund grants are gratefully acknowledged. I thank David Ayre, Libby Howitt, Peter Weston and Rob Whelan for their support and comments on various drafts of this manuscript. This is publication no. 147 from the Ecology and Genetics Group of the University of Wollongong.

\section{References}

AYRE, D. J., WHELAN, R. J. AND REID, A. 1994. Unexpectedly high levels of selfing in the Australian shrub Grevillea barklyana (Proteaceae). Heredity, 72, 168-174.

BENSON, D. H. 1985. Maturation periods for fire-sensitive shrub species in Hawkesbury sandstone vegetation. Cunninghamia, 1, 339-349.

BRADSTOCK, R. A. 1990. Demography of woody plants in relation to fire: Banksia serrata Lf. and Isopogon anemonifolius (Salisb.) Knight. Aust. J. Ecol., 15, 117-132.

BRown, A. H. D. 1979. Enzyme polymorphism in plant populations. Theor. Pop. Biol., 15, 1-42.

CARTHEW, s. M. 1993. Population genetic structure of Banksia spinulosa. Heredity, 70, 566-573.

CARY, G. J. AND MORRISON, D. A. 1995. Effects of fire frequency on plant species composition of sandstone communities in the Sydney region: combinations of inter-fire intervals. Aust. J. Ecol., 20, 418-426.

COATES, D. J. AND SOKOLOWSKI, R. E. S. 1992 . The mating system and patterns of genetic variation in Banksia cuneata A. S. George (Proteaceae). Heredity, 69, 11-20.

HAASE, P. 1992. Isozyme variability and biogeography of Nothofagus truncata (Fagaceae). N. Z. J. Bot., 30, 315-328.

HAMRICK, J. L. AND GODT, M. J. w. 1989. Allozyme diversity in plant species. In: Brown, A. H. D., Clegg, M. T., Kahler, A. L. and Weir, B. S. (eds) Plant Population Genetics, Breeding and Genetic Resources, pp. 43-63. Sinauer Associates, Sunderland, MA.

HAMRICK, J. L., GODT, M. J. W. AND SHERMAN-BROYLES, S. L. 1992. Factors influencing levels of genetic diversity in woody plant species. New Forests, 6, 95-124.

HOPE, G. 1984. Australian environmental change: timing, directions, magnitudes and rates. In: Martin, P. S. and Klein, R. G. (eds) Quaternary Extinctions: A Prehistoric 
Revolution, pp. 681-690. University of Arizona Press, Tucson, AZ.

KRAUSS, S. L. 1994. Restricted gene flow within the morphologically complex species Persoonia mollis (Proteaceae): contrasting evidence from the mating system and pollen dispersal. Heredity, 73, 142-154.

KRAUSS, s. L. 1995. Systematic pattern and evolutionary process in the complex species Persoonia mollis (Proteaceae). Ph.D. Thesis, University of Wollongong.

KRAUSS, S.L. A multivariate analysis of geographic variation in morphology in the complex species Persoonia mollis (Proteaceae). Pl. Syst. Evol. (in press).

KRAUSS, s. L. AND JOHNSON, L. A. s. 1991. A revision of the complex species Persoonia mollis (Proteaceae). Telopea, 4, 185-199.

LEDIG, F. T. 1986. Heterozygosity, heterosis and fitness in outbreeding plants. In: Soulé, M. E. (ed.) Conservation Biology: the Science of Scarcity and Diversity, pp. 77-104. Sinauer Associates, Sunderland, MA.

LESSA, E. P. 1990. Multidimensional analysis of geographic genetic structure. Syst. Zool., 39, 242-252.

LESSIOS, H. A. 1992. Testing electrophoretic data for agreement with Hardy-Weinberg expectations. Mar. Biol., $112,517-523$.

LEWIS, P. O. AND CRAWFORD, D. J. 1995. Pleistocene refugium endemics exhibit greater allozymic diversity than widespread congeners in the genus Polygonella (Polygonaceae). Am. J. Bot., 82, 141-149.

MITTON, J. B. AND GRANT, M. C. 1984. Associations among protein heterozygosity, growth rate, and developmental homeostasis. Ann. Rev. Ecol. Syst., 15, 479-499.

MORAN, G. F., MUONA, O. AND BELL, J. C. 1989. Acacia mangium: a tropical forest tree of the coastal lowlands with low genetic diversity. Evolution, 43, 231-235.

NEI, M. 1978. Estimation of average heterozygosity and genetic distance from a small number of individuals. Genetics, 89, 583-590.

NEI, M. 1987. Molecular Evolutionary Genetics. Columbia University Press, New York.

NEI, M. AND CHESSER, R. K. 1983. Estimation of fixation indices and gene diversities. Ann. Hum. Genet., 47, 253-259.

PORTER, A. H. 1990. Testing nominal species boundaries using gene flow statistics: the taxonomy of two hybridizing admiral butterflies (Limenitis: Nymphalidae). Syst. Zool., 39, 131-147.

QIU, Y.-L. AND PARKs, C. R. 1994. Disparity of allozyme variation levels in three Magnolia (Magnoliaceae) species from the southeastern United States. Am. J. Bot., 81, 1300-1308.

SAMPSON, J. F., COLLINS, B. G. AND COATES, D. J. 1994. Mixed mating in Banksia brownii Baxter ex $\mathrm{R}$. Br. (Proteaceae). Aust. J. Bot., 42, 103-111.

SELANDER, R. K., SMITH, M. H., YANG, S. Y., JOHNSON, W. E. AND GENTRY, J. B. 1971. Biochemical polymorphism and systematics in the genus Peromyscus. I. Variation in the old-field mouse (Peromyscus polionotus). In: Studies in Genetics, vol. 6, pp. 49-90. University of Texas Publication 7013.

SIDDIOI, M. Y., CAROLIN, R. C. AND MYERSCOUGH, P. J. 1976. Studies in the ecology of coastal heath in New South Wales. III. Regrowth of vegetation after fire. Proc. Linn. Soc. N.S.W., 101, 53-63.

SINGH, G., KERSHAW, A. P. AND CLARK, R. 1981. Quaternary vegetation and fire history in Australia. In: Gill, A. M., Groves, R. H. and Noble, I. R. (eds) Fire and the Australian Biota, pp. 23-54. Australian Academy of Science, Canberra.

SLATKIN, M. 1987. Gene flow and the geographic structure of natural populations. Science, 236, 787-792.

SOLTIS, D. E., HAUFLER, C. H., DARROW, D. C. AND GASTONY, G. J. 1983. Starch gel electrophoresis of ferns: a compilation of grinding buffers, gel and electrode buffers and staining schedules. Am. Fern J., 73, 9-27.

SWOFFord, D. L. AND SELANDER, R. B. 1989. BIOSYS-1: $A$ computer program for the analysis of allelic variation in population genetics and biochemical systematics. Release 1.7. University of Illinois, Urbana, IL.

TURNER, M. E., STEPHENS, J. C. AND ANDERSON, w. W. 1982. Homozygosity and patch structure in plant populations as a result of nearest-neighbor pollination. Proc. Natl. Acad. Sci. U.S.A., 79, 203-207.

WADE, M. J. AND McCAUlEY, D. E. 1988. Extinction and recolonisation: their effects on the genetic differentiation of local populations. Evolution, 42, 995-1005.

WENDEL, J. F. AND WEEDEN, N. F. 1989. Visualization and interpretation of plant isozymes. In: Soltis, D. E. and Soltis, P. S. (eds) Isozymes in Plant Biology, pp. 5-45. Dioscorides Press, Portland, OR.

WHITKUs, R. 1988. Modified version of GENESTAT: a program for computing genetic statistics from allele frequency data. Plant Genet. Newsl., 4, 10.

WRIGHT, s. 1946. Isolation by distance under diverse systems of mating. Genetics, 31, 39-59. 